\title{
Journey to the Past: History of Thyroid Surgery
}

\author{
Jae Hong Park \\ Department of Otolaryngology-Head and Neck Surgery, Soonchunhyang University College of Medicine, Cheonan, Korea
}

\section{흥미로운 갑상선 수술의 역사: 고대부터 현대까지}

박 재 홍

순천향대학교 의과대학 이비인후과학교실

Received January 29, 2016

Revised March 14, 2016

Accepted March 17, 2016

Address for correspondence

Jae Hong Park, MD

Department of Otolaryngology-

Head and Neck Surgery,

Soonchunhyang University

College of Medicine,

31 Suncheonhyang 6-gil,

Dongnam-gu, Cheonan 31151, Korea

Tel $+82-41-570-2265$

Fax $+82-41-579-9022$

E-mail entparkong@hanmail.net
History of the thyroidectomy is a history in the advancement of surgery itself. Prior to the 19 th century, the surgery of thyroid gland was clouded in lack of understanding. However, references to the thyroid disease and its treatment can be found in the literature and paintings of ancient medicine. Due to the lack of awareness and poor nutrition including iodine deficiency, Thyroid disease like goiter was widespread in that era. Many physicians had described the thyroid disease in various explanations and had attempted to cure that disease in many ways which was not on the scientific basis. By the 19th century, reasonable basis and explanation of the thyroid gland and its disease enabled the surgical treatment with resecting thyroid gland. However, like other surgery, surgical resection of the thyroid gland was limited by the lack of anesthesia, proper instruments and antibiotics in that time. Much of the progress in thyroid surgery occurred in 20th century by the contribution of the pioneering European and American surgeons with the advances of the surgical technique using proper instrument, antisepsis and biochemical products. Nowadays, modern imaging methods and remarkable surgical devices like endoscope or robot allow the variable access to the thyroid gland, which can be an alternative to the conventional method.

Korean J Otorhinolaryngol-Head Neck Surg 2016;59(8):563-70

Key Words History - Thyroid disease - Thyroidectomy.

\section{갑상선 질환의 역사}

갑상선은 20세기에 이르러서야 그 과학적인 이해와 지식의 토대가 마련되었다 해도 과언이 아닐 만큼 미지의 분야였다. 비록 정확한 의학 지식을 바탕으로 한 기술은 아니었을지라 도 갑상선 질환에 대한 기록은 고대 중국, 인도, 이집트, 그리 스의 문헌과 그림에서 발견할 수 있으며 생리학적 지식이 없 었기에 대부분 갑상선종을 기술한 것들이었고, 그에 대한 치 료 또한 대부분 미신적인 행위에 그치긴 했으나 일부 기록은 요오드 보충요법과 연관된 치료까지 문화별로 다양하게 기록 되어 있다. 다양한 문화권에서 이렇듯 공통된 기록이 고대로 부터 남아 있는 것으로 보아 전 문화권에 걸쳐 상당한 유병률 을 보였을 것으로 짐작할 수 있으며, 갑상선 질환에 대한 무지
와 요오드결핍을 포함한 영양불균형으로 인해 현재보다 유병 률은 더 높았을 것으로 예상할 수 있다. 그에 반해 치료는 요 오드를 포함한 해초류를 환자에게 먹게끔 했다는 기록과 종 창부위를 가열된 금속 기구로 소작했다는 기록 외에는 의학 적인 효과를 기대하긴 힘들었으며, 근현대에 이르러서야 비 로소 수술적인 치료를 시도한 기록은 있으나, 안전한 마취술 과 적절한 수술기구가 존재하지 않았기에 초기 갑상선 수술 의 사망률은 매우 높아 위험한 수술로 기피되었다고 한다. ${ }^{1-3)}$ 20세기에 들어 마취와 소독의 개념을 도입한 수술법, 항생제 및 적절한 수술기구의 개발로 인해 갑상선 수술의 비약적인 발전이 있었고 갑상선 수술의 발전사는 수술 그 자체의 발전 사라 해도 과언이 아닐 만큼 의학 전반에 걸친 수술적 치료의 발전과 그 과정을 함께 했다고 볼 수 있다. 


\section{고대(기원 전시대 기원 후 4세기)}

\section{한 국}

고대 한국의 의학서에는 갑상선이라는 용어는 물론 존재하 지 않는다. 아마도 삼면이 바다로 둘러싸여 해산물을 그리 어 렵지 않게 구할 수 있었으며 천일염을 이용한 젓갈, 된장, 간 장을 섭취하였기에 요오드 부족에 의한 갑상선 종창이 흔하 지는 않았을 것으로 추정될 뿐이다. 다만, 후대에 허준이 저술 한『동의보감』에 중국의 황제내경을 비롯한 고대의학서에서 인용한 내용 중 깊은 산속에서 오래 살게 되면 목 앞쪽에 툭 튀어나온 혹이 발생한다는 병증에 대한 소개가 있기는 하다. ${ }^{4)}$

\section{중 국}

고대의 갑상선에 대한 최초의 기록은 3500년 이상 오래 된 것으로 대부분 종양에 대한 언급이 주를 이룬다. 기원 전 2700 년 Shen Nung이 기록한 중국의 문헌에서는 갑상선 종양을 경부에 발생하는 가장 흔한 종물로 기술되어 있으며, 갑상선 종창을 치료하기 위해 해초류와 해면류를 사용하였다는 기 록이 존재한다. 기원 후 85년 중국의 Tshui Chih-Thi는 갑상 선종물을 경성종물과 연성종물로 구분하여 기술하였으며 전 자는 치료가 불가능하다고 여겼고 후자는 양성종물로 기술 하여 예후에 따른 갑상선의 악성종양과 양성종양을 구분한 첫 기록으로 알려져 있다.,5)

\section{힌 두}

힌두의 성전인 Ayurveda 소개되고 있는 힌두의사 Charaka 에 의한 기록에는 갑상선종양과 갑상선 기능저하증에 대한 기 술과 함께 이를 예방할 수 있는 방법으로 사탕수수, 보리, 쌀, 오이, 우유 등을 충분히 섭취하면 예방할 수 있다 하여 요오 드보충요법을 설명하는 내용과 함께 갑상선 기능저하증 증상 에 대한 기술과 다양한 허브를 이용하여 대사량을 증가시키 고 이뇨효과를 이용하여 부종을 감소시키는 치료법을 소개하 고 있다.

\section{이집트-그리스-로마}

반면, 고대인들이 갑상선의 해부생리학적 이해가 부족했 던 탓에 다소 미신적인 요소가 포함된 기술이나 갑상선 질환 을 타 질환의 합병증으로 오해한 기술 또한 흔히 발견할 수 있는데 대표적으로 고대 이집트에서는 전경부의 종창, 즉 갑 상선의 종양 또는 종창이었을 것으로 추정되는 증상을 가진 환자에게 시체의 손으로 두드리거나 두꺼비 기름을 이용한 치료법이 기록되어 있고 히포크라테스는 눈이 녹은 물을 마 셔서 발생한 경부 분비샘의 이상으로 기록하였으며, 후대의
고대 로마의 의학자들은 갑상선 종창을 기관벽의 이상으로 인한 경부전방으로의 기관지탈출증으로 이해하여 기술한 바 도 있다. 사실 현대 의학용어로 'goiter'라는 단어 역시 라틴 어로 목 또는 인두, 후두를 뜻하는 'gutter'에서 기원한 사실을 보면 인두질환 또는 해부학적인 변이와 이상이 갑상선 질환과 연관되어 있다는 견해를 반영한 결과라고 사료된다. ${ }^{8,9)}$ 이러 한 관찰의 기록들이 현재의 관점에서 보면 다소 엉뚱하다 할 수 있을 수는 있지만 당대로서는 아주 근거 없는 사실들을 기술한 것은 아니었을 것으로 추정된다. 저자의 견해로 보면 두꺼비 기름은 요오드를 포함하고 있어 이를 먹거나 다른 방 법으로 흡수되게 하였다면 이는 요오드 부족으로 인한 갑상 선종창을 요오드 보충요법을 이용한 치료였기에 마냥 비과 학적이라고만은 할 수 없으며 히포크라테스의 견해 또한 눈 이 녹은 물은 갑상선 질환의 직접적인 원인이 될 수는 없지 만 요오드가 포함되지 않은 물로 인해 요오드부족 증상과 갑상선 질환을 연관시킬 수는 있을 것이다. 또한 로마인들의 기관지탈출증설 역시 기관벽에 갑상선이 붙어 있어 이에 대 한 해부학적 견해였다고 풀이할 수 있다.

\section{중세(5세기 15세기)}

중세에 들어 갑상선에 대한 이해는 해부학을 바탕으로 한 보다 과학적인 지식을 근간으로 하였고 갑상선 질환에 대한 보다 체계적인 관찰을 통해 치료에 접근하고자 하였다. 이 시 기의 갑상선 질환에 대한 수술적 치료는 기도폐쇄의 경우에 한해서 시도된 기록들이 대부분이지만 후두신경에 대한 기 술, 소작기, 세침흡인술 등에 대한 기술과 같은 놀라운 기록 들이 나오게 된다.

\section{초기 비잔틴-페르시아}

6세기 Aetius는 갑상선 종창에 대한 수술적 치료와 이와 연 관된 후두신경 손상을 언급하며 후두신경을 보존하는 수술 적 치료를 기술하였고 갑상선 종창의 원인을 경부로의 후두 탈출증으로 여겨 이에 대한 견해를 기록하였으며 딱딱한 고 형이 아닌 죽성형태의 연성종괴를 소개하기도 하였다. 7세기에 이르러는 Paulus Aegineta가 수술적 치료의 경험을 바탕으로 갑상선 종양을 밝은 색의 'steatomatous goiter'와 붉은 빛의 'hyerplastic or hyperemic goiter'로 분류하기도 하였다.,9-11)

갑상선 질환과 연관된 안질환 또한 기원 후 1000 년과 1110 년 페르시아의 의학자이자 철학자였던 Avicenna와 Aj-Jurjani 에 의해 최초로 기록되었다. 당시의 기록을 보면 전경부 종창 을 가진 환자에서 안구돌출을 보이는 사례들을 기술하였고 신경과민증을 언급하여 후세의 그레이브스병으로 명명된 질 
환의 최초 기록으로 여겨진다. ${ }^{912)} 7$ 세기 많은 비잔틴 예술가들 의 그림과 조각상에서도 갑상선 종창이 표현되어 있는데 당 시 예술작품에서 발견되는 질환 중 가장 많이 표현되어 있다 고 한다. 그런데, 이후의 예술작품 속 성자, 성인을 표현한 모 습에서도 갑상선 종창을 볼 수 있는 점을 보아 당시 그림의 모 델들 중 상당수가 갑상선 질환 환자였을 것으로 추정된다. ${ }^{13)}$

\section{무 어}

갑상선 수술에 대한 최초의 상세한 기록은 기원 후 952년 무 어인 의사 Abu Alkasem Al Zehrawi(Albucasis로 기록되기도 함)에 의해 본인의 의학서 'Al-Tasreef'에 기술되어 있다. 그의 기록에 의하면 거대한 갑상선 종양을 가진 남자 환자를 대상 으로 한 종양절제술로 현대의 수술 및 마취법과 그 원리에 있 어 유사한 수술법이 기술되어 있어 놀라움을 금치 못 한다. 그 는 수술 시 출혈을 조절하기 위해 고열로 가열한 금속을 이용 하여 출혈부위를 소작하는 법과 실을 이용한 혈관 결찰술을 소개하고 있으며 목 주변에 수술 시 흘러내리는 혈액을 받아 내는 커다란 주머니를 환자의 목에 두르고 수술하였다 하며 놀라운 점은 수술 시 통증을 줄이기 위해 아편을 이용한 마취 후 수술을 시작하였고 기타 현대에도 사용되는 다양한 겸자, 주사기 및 소작기와 유사한 기구들을 이용하였고 심지어 현 대의 세침흡인술과 비슷한 방법도 이용하였다는 사실이다. ${ }^{14)}$

\section{로마-유럽}

중세의 갑상선 수술은 대부분 고대의 기록에서 수술방법 에 대한 기원을 찾을 수 있는 데도 불구하고 수 세기에 걸쳐 수술과 관련된 합병증 및 높은 사망률로 인해 기도폐쇄로 인 한 경우 외에는 적극적으로 시도되지 않았다. 1170년 Roger Frugardi는 뜨겁게 달군 두 개의 금속철사 및 부식성 분진 을 이용한 소작술과 이를 이용하여 효과가 없을 시에는 칼과 손가락을 이용한 절제술을 권하는 내용을 기록한 바 있는데 Frugardi는 손가락을 주로 이용한 수술 시 손톱을 갑상선 박 리에 사용하였고, 갑상선에 대한 정확한 해부생리학적 지식 없이 시행된 이러한 수술결과 합병증 및 사망률이 매우 높았 던 것으로 전해진다. ${ }^{15-17)} 14$ 세기에 이르러는 프랑스 외과의사 Guy de Chaliac이 갑상선종은 유전질환이며 수술적 치료의 필요성을 기술하기도 하였으나 여전히 출혈, 감염, 색전증, 기 도손상 및 폐색으로 인한 높은 사망률로 환자와 의사에게 갑상선 수술은 공포의 대상이었다. ${ }^{17,18)}$

\section{근대(르네상스, 16세기 18세기)}

16세기에 이르러 이전의 높은 유병률에도 불구하고 이름
조차 없던 갑상선의 해부학적 형태, 구조 및 이름이 명명되게 되는데 이후 Thomas Wharton에 의해 그리스 방패모양을 본 따 ‘thyroid’라는 이름으로 최초로 명명되어 갑상선이 비로소 독립된 장기로 인식되기 시작하였고 1511년 Leonardo Da Vinci의 인체해부도에 자세히 묘사되었다. ${ }^{19,20)}$ 그러나, 당시 그는 갑상선의 해부학적 구조는 정확히 표현했지만 그 기능 에 대해서는 몰랐기에 해부도 가장자리의 설명에는 '근육이 없는 공간을 메우기 위해 존재하며 기관을 흥골절흔에 고정 하기 위해 존재한다고 기술하였다. 이후 Andreas Vesalius에 의해 해부학적인 기술과 도해가 다시 기록되었고 Bartholomeo Eustachius는 갑상선의 양측 두 엽이 중간의 협부를 통해 이 어져 있는 구조를 기술하며 "isthmus'라는 용어를 소개하였 다. 1656년 Thomas Wharton은 그의 인체분비샘에 대한 저 술에서 그리스어로 방패를 뜻하는 'thyreos'라는 단어에서 파생한 'glandulae thryroideae'라는 신조어를 만들어 냈고 이 것이 바로 갑상선에 대한 최초의 명명으로 인정되고 있다. ${ }^{21)}$ 하지만 19세기 초까지의 갑상선 수술은 매우 위험한 수술로 인식되었고 사망률은 40\%에 이르러 1646년 프랑스에서는 외 과의사가 갑상선 수술로 인해 감옥에 투옥되기도 하며 이후 1850년에는 갑상선 수술이 프랑스 의학회에 의해 금지되기에 이른다. Frugardi(1170), De Vigo(1501 1512), Lusitanus(1550), Desault(1791)와 같은 당대 저명한 외과의들에 의한 성공적 인 갑상선 부분절제술의 기록이 있지만 이는 매우 제한적이 며 이후 19 세기 초까지 적절한 수술기구와 마취법의 부재, 감 염의 문제로 인해 갑상선 수술은 정체기를 맞는다. ${ }^{19-24)}$ 다만 18 세기 말에서 19 세기 초에 이르는 시기에 갑상선의 생리적인 기능에 대한 호기심으로 하여금 새로운 학설들이 제기되었고 이 중 Frederik Ruysch는 갑상선에서 특정한 액체가 나와 정 맥으로 유입된다고 여겼으며 Caleb Hillier Parry는 갑상선 이 뇌의 충혈을 막기 위한 혈류의 저장소 역할을 한다고 여긴 점으로 보아 아직 갑상선에 대한 생리학적 지식이 전무하였 다고 할 수 있다. ${ }^{25)}$

\section{9세기 20세기 초}

19세기 초반까지도 갑상선 수술은 아직 고대의 것과 다르지 않을 정도의 수준이었다. 19 세기 초 갑상선의 부분절제술과 종물을 부분적으로 절제하여 크기를 줄이는 수술이 한때 많 이 시도되었으나 수술기법의 비효율성과 수술결과의 위험성 으로 인해 관심을 받지 못했다. 그러나 이 시기에 요오드결핍 으로 인한 갑상선종이 처음 알려지기 시작하여 후대의 요오 드결핍과 관련된 지역성 갑상선종의 발견에 기여하게 된다. Malacarne는 1789년 그의 저서에서 이탈리아와 프랑스의 
산악 지역에 국한된 경부종물과 지능저하에 대하여 기술하 였으나 당시 요오드라는 물질에 대한 지식이 없었기에 지능 저하는 뇌로 가는 혈류를 경부종물이 차단하여 발생하는 것 으로 여겼다. ${ }^{26)} 19$ 세기 중반에 들어 마취, 방부법, 병리학, 미 생물학 및 생화학의 발달과 더불어 갑상선 수술은 급진적으 로 발전하게 된다. 수술용 장갑 또한 1890년 William Stewart Halsted의 의뢰로 Goodyear Tire \& Rubber(AKron, OH, USA) 회사에서 최초로 수술용 고무장갑을 개발하게 되었으 며 이후 1964년 Ansell 회사에 의해 일회용으로 된 라텍스 장갑이 제조되면서 의료용 장갑의 사용이 활발해졌다. 그 외 에 혈관 결찰용 겸자와 같은 효과적인 수술기구들의 개발로 더욱 안전한 수술이 가능해짐과 더불어 병리학과 생화학의 발달로 인해 갑상선의 생리학적 기능과 질환의 병태생리를 차츰 이해하게 된 시기라 할 수 있다. ${ }^{17,23,27)}$

\section{방부법}

19세기 초까지만 해도 수술 후 감염으로 인한 합병증과 사 망률이 매우 높았기에 Theodor Billroth와 같은 당대의 많 은 뛰어난 외과의사들 조차도 기도폐색과 관련된 응급수술 을 제외하고는 갑상선 수술을 기피할 정도로 갑상선 수술 후 전경부의 감염은 치명적인 경우가 많았다. 1867년 Lister에 의해 도입된 석탄산(페놀, carbolic acid)을 이용한 무균수술 은 수술 후 감염률을 현저히 감소시키며 사망률을 저하시키 는 중요한 인자가 되었다. ${ }^{17,28}$

\section{마취와 수술기구의 개발}

전신마취가 개발되기 전 시대의 수술은 통증을 고스란히 느끼게 되는 환자에게는 극도의 공포를 체험하는 경험이었 다. 19세기 후반 생화학의 발달은 에테르를 포함한 다양한 화 학물질을 마취에 이용할 수 있게 하였고 전신마취를 가능하 게 하였다. 전신마취법이 도입된 이래로 환자들은 고통을 느 끼지 않게 되었고 의사들은 보다 편안하게 수술할 수 있게 되 었으며 이로 인해 다양한 부위의 많은 수술이 가능하게 되었 으며 많은 경험이 쌓이자 선도적인 외과의들에 의해 혈관결 찰용 겸자와 같은 유용한 기구들 또한 이 시기에 개발되기에 이른다. 방부법, 전신마취 및 수술기구의 발전은 수술 후 합병 증의 감소와 사망률의 감소로 이어지게 되어 19세기말 Theodor Kocher는 $1 \%$ 이내의 사망률을 보고하게 된다. 반면, 전 신마취의 발달에도 불구하고 거대한 갑상선종의 경우 당시 까지는 마취 중 안전한 기도확보법이 확립되지 않아 여전히 국 소마취로 수술을 시행했다고 한다. ${ }^{5,17)}$

\section{갑상선의 생리학적 이해}

17세기 네덜란드의 Antonie van Leeuwenhoek에 의해 최 초로 발명된 현미경은 19세기에 이르러 의학분야에 널리 쓰 이며 미생물학 및 생화학의 발달에 기여하게 된다. 이를 통해 1811년 고대의 중국 문헌에도 소개된 바 있는 해초류를 태운 재에서 요오드를 처음 발견하게 되며 1820년에는 요오드를 이용한 성공적인 갑상선종의 치료가 보고되게 된다. 당시의 기록에 의하면 기관을 압박하는 거대한 갑상선종을 요오드 를 복용하게끔 하여 크기를 줄이는 데 성공하였으며 이를 통 해 응급에 해당하는 갑상선 수술을 줄였다고 한다. ${ }^{16)}$ 그러나 요오드를 이용한 치료가 항상 성공적인 것은 아니었다. 오히 려 부작용 또한 보고되어 요오드 치료에 대한 논란은 당시 의학자들로 하여금 요오드와 연관된 갑상선 생리를 연구하 게 되는 계기가 되었고 이로 인해 갑상선 생리에 대한 이해에 한 발짝 다가서게 되었다. 당시 과학자들은 갑상선이 분비하 는 특정 액체를 생성하기 요오드를 필요로 하며 이를 저장한 다는 사실까지 발견하게 된다. 이는 이후에 발견하게 되는 많 은 갑상선생리연구의 기폭제가 되며 실제 요오드를 이요한 치 료사례가 발표된 직후인 1825년 Parry, 1835년 Graves, 1835 년 Basedow에 의해 안질환을 동반한 갑상선 기능항진증이 특유의 증상들에 대한 기술과 함께 발표된다. ${ }^{19,23)}$ 이후 갑상 선중독증에 대한 치료가 시도되지만 초기에는 갑상선을 제 거한 염소의 젖과 혈청을 환자에게 먹이거나 동물의 다양한 분비샘에서 추출한 분비액을 먹이는 등의 치료법이 전부였 다. 20 세기 초에 이르러서야 비로소 방사성 물질과 인슐린을 통해 갑상선기능을 감소시키는 방법이 시도되었다. 갑상선 기능저하증은 1850 년 Thomas Curling에 의해 처음 기술된 이후 1875년 William Gull과 이후 Theodor Kocher에 의해 서도 보고되며 갑상선기능항진증과 더불어 갑상선기능저하 증에 대한 연구를 통해 갑상선호르몬의 역할을 이해하게 되 었다. ${ }^{25}$ 19세기 중반 Moritz Schiff는 갑상선을 제거한 개는 죽는 데 반해 갑상선을 이식한 개는 생존함을 관찰한 실험에 서 갑상선 호르몬의 생리학적 중요성을 입증하였고 1888년 William Grieenfield는 갑상선중독증의 증상들이 갑상선의 비후와 연관되어 있다고 보고하였다. ${ }^{5)}$ 1890년 George Murray 와 Howitz는 동물의 갑상선에서 추출한 물질을 이용하여 갑 상선기능저하증을 성공적으로 치료하였고 이러한 연구들은 결국 20세기 초 갑상선 호르몬을 합성하게 되는 연구로 이어 지게 된다. ${ }^{25}$

\section{갑상선 수술 후 합병증}

19세기 후반 수술용 겸자의 도입을 시작으로 갑상선 수술이 급격히 늘게 되며 갑상선 수술 후의 합병증에 대한 보고 또한 
이 시기에 활발하게 이루어지게 된다.

\section{테타니}

1891년 Gley는 갑상선 수술 후에 나타나는 경련을 부갑상 선의 절제 또는 주변 혈류의 차단과 관련되어 발생한다고 보 고하였고 ${ }^{29)}$ 뒤이어 1896 년 Vassale과 Generalim의 동물실험 을 통해 갑상선 수술 후 테타니와 부갑상선기능과의 연관성 이 입증되었다. ${ }^{30)}$ 이후 Bilroth의 제자였던 Anton Wolfler, Johann Mikulicz에 의해 테타니를 막기 위해 부갑상선을 보존 하는 수술법이 소개되기도 하였다. ${ }^{31)}$ 20세기 초 Halsted와 Evans에 의해 부갑상선의 혈류가 명확히 규명되었고 이후 MacCallum ${ }^{32}$ 에 의해 갑상선 수술 후 테타니가 칼슘 저하로 인 한 것이 밝혀져 테타니의 치료로 칼슘이 사용되기 시작하였다.

\section{후두신경손상}

2세기에 Claudius Galen의 다양한 동물에 대한 해부연구 에서 후두신경과 손상 시의 음성변화를 처음 기술하였지만 19 세기 이전에는 후두를 관찰할 수 있는 검사법이 없었기에 갑 상선 질환과 관련된 후두기능이상은 진단하기 힘들었다. 19세 기 후반 Mikulicz, Wolfler가 처음으로 갑상선 수술 시 부갑 상선의 보존과 함께 후두신경의 보존을 강조하였고 이들에 의해서 갑상선의 후방부위를 보존하여 부갑상선과 후두신경 의 기능을 보존하기 위한 수술법이 소개되었다. ${ }^{17)}$ 반회후두 신경에 대한 당시의 관심과는 달리 20세기 초에 이르기까지 도 상후두신경에 대한 연구는 미미하였다. 1935년 당시 유명 한 소프라노였던 Amelita Galli-Curci의 증례는 상후두신경 의 기능과 이에 대한 보존의 중요성을 깨닫게 되는 계기가 되 었다. 거대한 갑상선종으로 인해 심한 기관의 전위 소견까지 보였던 Galli-Curci는 Kegel과 Dunleavy에 의해 갑상선 절 제술을 시행받게 되었고 수술 후 수 개월간의 회복기간 후에 다시 무대에 오른 그녀의 공연을 듣고 많은 팬들과 비평가들 은 그녀의 고음역대 발성에 이상이 있음을 알게 된다. 당시로 써는 매우 생소한 합병증이었던 이유로 많은 논란이 있었으 며, 이 사례를 통해 많은 외과의들이 상후두신경에 관심을 갖 고 보존하려 노력하게 된다. ${ }^{33)}$

\section{갑상선 수술의 위대한 개척자들}

\section{Theodor Billroth(1829 1894)}

근현대사 통들어 Billroth와 같은 외과의는 찾기 힘들 정도 로 그는 다양한 분야의 수술에 탁월한 업적을 남겼다. 그는 베를린 의과대학을 졸업하고 스위스 취리히, 오스트리아 빈 에서 외과의사로 근무하며 많은 제자들을 양성하였다. 심지
어 그의 제자들 역시 다방면에 뛰어난 외과의들이었고 후대 에 갑상선 수술의 아버지로 불리는 Theodor Kocher 역시 오 스트리아 빈에서 Bilroth의 수술을 참관하였던 사실로 보아 Bilroth는 훌륭한 외과의이자 동시에 훌륭한 교육자였음은 틀림없다. 하지만, 갑상선 수술에 대한 그의 견해는 비관적이 었다. 물론 그가 왕성히 활동했던 19세기 중반까지는 무균수 술이나 효과적인 마취법이 없었으며 지혈에 혈관결찰용 겸자 와 같은 적합한 수술기구 또한 다양하게 개발되어 있지 않아 목 앞의 좁은 부위의 커다란 혹을 제거하고 겸자도 없이 지혈 해야 하는 수술이 결코 쉽지 않았을 것이다. 게다가 수술 후 출혈뿐만 아니라 감염 또한 치명적일 수 있었던 시기여서 그 의 갑상선 수술 후 사망률은 높을 수밖에 없었다. 그는 갑상 선 수술을 응급이 아닌 경우에는 하지 않아야 한다고 여겼으 며 실제 취리히에서의 20예의 갑상선 수술 후 $40 \%$ 의 높은 사망 률을 보고한 이후 10 년간 갑상선 수술을 하지 않았다고 전해 진다. ${ }^{17,28,34)}$

\section{Theodor Kocher(1841 1917)}

Theodor Kocher는 스위스 베른에서 기술자의 아들로 태어 나 독어, 불어 등 다국어를 혼용하여 사용하는 스위스에서 자란 덕에 영어, 독어, 불어에 능통하였고 실제 베른 의과대 학 졸업 이후 외과의로의 수련과정에서 취리히, 베를린, 런 던, 빈에서 다양한 경험을 쌓게 되고 이 시기에 당대 최고의 외과의였던 Theodor Billroth의 수술을 참관하게 되며 이는 실제 그의 수술에 지대한 영향을 미치게 된다. 졸업 이후 모 교인 베른 의과대학에서 근무 시 경제적인 이유로 대학을 떠 나 잠시 개인의원을 개업하여 운영했던 시기에도 수 많은 논 문을 여러 나라의 학회에 발표할 정도로 임상연구에 관심이 많았으며, 당시 그의 연구결과를 유럽의 다양한 국가에 게재 할 수 있었던 배경에는 그의 탁월한 언어능력도 한몫을 했던 것으로 생각된다. 그의 수술이 남달랐던 점은 출혈이 많을 수밖에 없는 갑상선 수술을 시행함에 있어 정교한 갑상선 피 막내 박리와 혈관의 결찰을 통해 수술 시 출혈량을 최소화 하였고 마취법에 대한 관심도 지대하였다고 한다. ${ }^{35-38)}$

그의 초기 수술들에서는 흥쇄유돌근의 전연부를 따라 고 안된 사선의 절개법 또는 경부 중앙의 수직절개를 이용하였 으나 후에는 현재와 같은 경부 중심의 경부횡절개를 이용하 였다. 그는 클로로포름을 이용한 마취와 관련된 환자의 사망 사례 이후 코카인을 이용한 국소마취만을 이용했다고 전해 지고 있으며 베른의과대학에서의 초기 10년간 101예의 갑상 선종 수술에서 $12.8 \%$ 의 사망률을 보였으나 이후 1889 년까지 250예의 수술에서는 $2.4 \%, 1898$ 년까지 560예의 양성갑상선 종양에 대한 수술에서는 $0.2 \%$ 의 사망률을 보였으며, 그가 
76세로 사망하기 수 주 전까지도 마지막 갑상선 수술을 성공 적으로 마쳤다고 전해지고 있으며, 그가 평생 시행한 갑상선 종에 대한 5000예의 수술 중 사망률은 단지 $0.5 \%$ 에 그쳤다 고 하니 당대로서는 놀라운 성적이라 할 수 있겠다. 그의 100 년 전의 수술법이 현재의 수술법과 큰 차이점이 없다는 점은 그만큼 그의 수술적인 완성도가 높았다고 해석될 수 있겠다. ${ }^{17)}$ 그는 수술뿐만 아니라 갑상선의 생리학적 이해에도 많은 공헌 을 하였는데 대표적인 예로 cachexia thyreopriva 또는 cachexia strumipriva라고 일컬어지는 갑상선 전적출술 후의 갑상선기능저하증과 관련된 일련의 증후군을 발견하였고 갑 상선 악성종양에 대한 연구에서도 후대의 많은 발견의 시초 가 된 뛰어난 업적을 남겼다. 그가 평생 이룬 갑상선 생리, 병 리 및 수술에 대한 업적으로 1909년 노벨상을 수상하게 된 다. 노벨상 수상 연설에서 그는 갑상선 질환을 진단함에 있 어 가장 어려운 점은 갑상선 종양에 대한 진단보다 갑상선기 능항진증과 저하증을 감별하는 점이라고 표현하여 현재와 같은 호르몬 검사법 없이 이를 진단함이 얼마나 어려웠는지 를 가늠해 볼 수 있다. ${ }^{17,23,28,29,35)}$

\section{William Stewart Halsted(1852 1922)}

예일대 출신의 미국 외과의사 Halsted는 Kocher와도 친분 이 두터워 그의 집에 자주 머물며 Kocher의 수술을 참관하 기도 하였던 것으로 전해진다. 존스홉킨스 대학에 근무하던 시절 Halsted는 수술 전 페놀을 이용하여 자신과 간호사의 손을 소독하였는데 페놀 알러지가 심한 간호사가 손의 피부 에 심한 손상을 입는 것을 보고 Goodyear Tire \& Rubber 회 사에 의뢰하여 최초로 수술용 고무장갑을 개발하였으며 흥 미로운 사실은 Halsted가 그 고무장갑을 최초로 착용한 간 호사와 이후 결혼하게 된다.

그는 갑상선 수술을 술식에 따라 표준화하였고 정확한 해 부생리학적 지식을 토대로 정교한 수술을 시행한 인물로 평 가된다. 또한 갑상선 전절제술 후 부갑상선 이식법을 도입하 였으며 다양한 견인기, 겸자, 수술용 바늘, 메스와 박리기 등 의 갑상선 수술에 적합한 수술기구를 개발하여 활용하였고 그의 이러한 노력 덕분에 미국의 갑상선 수술은 비약적으로 발전하게 되었다. 마취법에 있어서도 국소침윤마취를 도입하 여 효과적인 수술이 가능하게 하였으며 1920년에 발간된 갑 상선종 수술에 대한 방대한 고찰을 담은 그의 보고서는 이후 갑상선수술의 체계를 확립하는 데 공헌하였다. ${ }^{17,23,28)}$

\section{Thomas Peel Dunhill(1876 1957)}

호주의 외과의 Dunhill ${ }^{39,40)}$ 은 그레이브스병에서 갑상선 전 절제술을 도입하였고 현재의 수술법과 가장 유사한 갑상선
피막주위의 정교한 절제술을 시행하였으며 흥골후방의 갑상 선종을 흥골절제를 통해 제거한 증례와 조절되지 않는 심방 세동 환자를 안전하게 수술하여 치료한 증례를 보고한 바 있 다. 이러한 위험한 증례들에도 불구하고 $3 \%$ 의 낮은 사망률 을 보고하였다. 당시 타 의료기관의 갑상선 수술 후 사망률이 $30 \%$ 까지 보고된 점으로 미루어 Dunhill의 성적은 놀라운 것 이었다고 할 수 있다. ${ }^{16}$

\section{Cecil Joll(1885 1945)}

영국의 외과의 $\mathrm{Joll}^{41)}$ 은 갑상선중독증을 갑상선 아전절제 술로 치료하는 방법을 자세히 기술하였고 1932년 그의 갑상 선중독증의 치료 경험을 토대로 "Diseases of the Thyroid Gland with Special Reference to Thyrotoxicosis」를 출간하 였다. 이 책에는 갑상선 아전절제술에 대한 내용과 함께 갑상 선중독발작(thyrotoxic crisis)에 대한 내용도 포함하고 있다.

\section{Charles H. Mayo(1865 1939)}

미국 갑상선 수술의 아버지라 불리는 Charles Mayo는 Kocher에 견줄만한 위대한 업적을 남긴 인물로 평가된다. 1907 년 Mayo는 처음으로 'hyperthyroidism'이라는 용어를 사용 하여 갑상선기능항진증의 증상들을 기술하였고, 1918년까지 5000예의 갑상선 수술을 토대로 갑상선기능항진증에 대한 많은 연구를 보고하였고, 갑상선 호르몬의 생리적인 기능을 많 은 부분 명확히 밝혀내었다. 또한 내과의사 Henry Plummer 와 함께 갑상선기능항진증 환자의 수술전 요오드 주입술을 최초로 시행하였고 이로 인해 3 4\%였던 사망률을 $1 \%$ 미만 으로 낮추었으며 재발에 의한 재수술률을 $50 \%$ 에서 $2 \%$ 로 낮추는 데 성공하였다. ${ }^{5,17,28)}$

\section{0세기 갑상선 수술의 진보}

20세기에 들어 많은 기초 의학 및 과학의 발달로 인해 갑상 선학에 있어서도 괄목할 만한 발견들이 있었다. 수술 시 수혈 이 가능하게 되었고 통계학의 도입으로 인해 갑상선 질환의 자료를 보다 정확하게 분석할 수 있게 되었으며 이러한 통계 기법은 후에 갑상선 악성종양에 대한 병리학적 소견, 임상경 과, 예후를 결합하여 분석한 병기분류의 시초가 되었다. 또한, 갑상선을 이식하는 개념도 소개된 바 있으며 1914년 Edward C. Kendall은 T4(thyroxine)를 분리하는 데 성공하여 후에 $\mathrm{T} 4$ (thyroxine)를 합성하여 상용화할 수 있는 초석을 세웠다. ${ }^{42)}$

이후 1940년대 초 항갑상선 제제와 방사성 요오드 치료가 개발되어 갑상선기능항진증 수술의 대안으로 사용되기 시작 하였고 1965년에는 Propranolol이 개발되어 갑상선중독증 환 자의 부정맥을 조절하는 데 사용되었다. ${ }^{25,43)}$ 
1952년에 처음으로 소개된 세침흡인세포검사는 1970년대 에 들어 널리 이용되었으며 1980년대에는 초음파의 보급과 함께 가장 유용한 진단법으로 자리매김을 하게 된다. ${ }^{44)}$

수술기구에 있어서도 지혈을 위한 전기소작기의 개발에 이 어 최근 Hemoclip과 같은 간편한 결찰기구와 LigaSure 또 는 Harmonic Scalpel과 같은 고주파를 이용한 지혈기구가 개발되어 100 여 년 전에 당시로서는 획기적이었던 실을 이용 한 혈관 결찰술을 대체하고 있다. 이러한 결찰기구의 개발과 더불어 광학 및 전자공학의 발달은 21 세기에 이르러 내시경 과 로봇을 이용한 수술을 가능케 하였고 이제는 100여 년 전 의 경부절개법 대신 후이개, 액와부 및 유륜부와 같이 보이지 않는 곳의 작은 절개만을 이용한 수술이 가능하게 되었다. ${ }^{45-47)}$ 또한, 수술 시 신경 감시장치를 이용하여 후두신경의 기능을 보다 안전하게 보존할 수 있게 되었다. ${ }^{47)}$

\section{결 론}

갑상선 수술의 역사는 중세 초기부터 그 기원을 찾을 수 있지만 효과적인 지혈법과 겸자와 같은 지혈도구, 갑상선의 기능과 생리에 대한 무지로 인해 위험한 수술로 여겨져 왔다. 근-현대를 지나는 동안 갑상선의 해부생리에 대한 이해, 효 과적인 결찰기구의 개발, 마취 및 방부법의 도입은 갑상선 수 술을 비약적으로 발전시키게 되었고 그로 인해 갑상선 질환 의 병태생리에 대하여 정확히 알 수 있게 되었으며 갑상선 호르몬의 역할과 이를 합성하여 치료에 이용하게 됨에 따라 현재의 갑상선 수술은 가장 안전한 수술 중 하나로 여겨지게 되었다. 그 술식에 있어서는 비록 100여 년 전과 크게 다르지 않지만 혈관 결찰용 겸자와 같이 오늘날 우리에게 흔히 접할 수 있는 기구 하나만으로도 수술 후 사망률이 크게 감소할 수 있었다는 사실은 그 만큼 수술기구의 개발 또한 중요한 역할 을 하였다고 볼 수 있으며, 초기 갑상선 수술이 의학계에서 외면당할 정도로 위험한 수술이었지만, 수술환경의 개선과 효과적인 기구의 개발은 갑상선 수술을 가장 흔하면서도 안 전한 수술 중 하나로 발전시켰다. 오늘날 우리에게 소개되는 내시경-로봇 갑상선 수술 또한 미래의 발전된 수술의 시초가 될 수도 있겠다는 가능성을 생각해본다.

\section{REFERENCES}

1) Choi JO, Jun BS, Sohn HS, Jung MH. Endoscopic thyroidectomy via axillary approach. Korean J Otolaryngol-Head Neck Surg 2006;49 (5):527-31.

2) Tae K. Robotic thyroidectomy. Korean J Otorhinolaryngol-Head Neck Surg 2010;53(8):463-9.

3) Kim JW, Kim DH, Cho BH, Kim BM, Kim YM. Video-assisted endoscopic thyroidectomy with cervical approach. Korean J
Otolaryngol-Head Neck Surg 2005;48(11):1363-8.

4) Ahn SY. Kabsangseonkeurlinik, 1st ed. Seoul: Seongbosa;2004.

5) Rogers-Stevane J, Kauffman GL Jr. A historical perspective on surgery of the thyroid and parathyroid glands. Otolaryngol Clin North Am 2008;41(6):1059-67, vii.

6) Lyons AS, Petrucelli RJ. Medicine: an illustrated history. New York: Abradale Press;1997. p.120-49.

7) Kalra S. Endocrinology in ayurveda: modern science, ancient history. Indian J Endocrinol Metab. In press 2011.

8) Hippocrates, Pedanius A, Kühn CG, Galenus C, Cappadox A, Petit P, et al. Medicorum Graecorum opera quae exstant: magni hippocratis opera omnia. Lipsiae: Cnobloch;1825-1827.

9) Amideni A, Zervos A. Liber XV. 1909;21:22-4.

10) Marketos S, Eftychiadis A, Koutras DA. Thyroid diseases in the Byzantine era. J R Soc Med 1990;83(2):111-3.

11) Aegineta P. The Seven books of Paulus Aegineta: translated from the Greek. with a commentary embracing a complete view of the knowledge possessed by the Greeks, Romans, and Arabians on all subjects connected with medicine and surgery by Francis Adams. London: Sydenham Society; 1844.

12) Nabipour I, Burger A, Moharreri MR, Azizi F. Avicenna, the first to describe thyroid-related orbitopathy. Thyroid 2009;19(1):7-8.

13) Józsa LG. Goiter depicted in Byzantine artworks. Hormones (Athens) 2010;9(4):343-6.

14) Annajjar J. Abu Alkasem Al Zehrawi (Albucasis 936-1013). Childs Nerv Syst 2010;26(7):857-9.

15) Bifulco M, Cavallo P. Thyroidology in the medieval Medical School of Salerno. Thyroid 2007;17(1):39-40.

16) Giddings AE. The history of thyroidectomy. J R Soc Med 1998;91 Suppl 33:3-6.

17) Becker WF. Presidential address: pioneers in thyroid surgery. Ann Surg 1977;185(5):493-504.

18) Leoutsakos V. A short history of the thyroid gland. Hormones (Athens) 2004;3(4):268-71.

19) Welbourn RB. The thyroid. In: Welbourn RB, editor. The history of endocrine surgery. New York: Praeger;1990. p.19-27.

20) Niazi AK, Kalra S, Irfan A, Islam A. Thyroidology over the ages. Indian J Endocrinol Metab 2011;15(Suppl 2):S121-6.

21) O'Malley CD, Saunders JB de CM. Leonardo on the Human Body. New York: Courier Corporation;1952. p.169-70.

22) Corner GW. Rise of medicine at Salerno in the twelfth century. Ann Med Hist 1931;3:1-16.

23) Halsted WS. The operative story of goitre: the author's operation. John Hopkins Hops Rep 1920;19:71-257.

24) Desault PJ. Giraud. Jour De Chir De Paris 1792;3:3.

25) Ahmed AM, Ahmed NH. History of disorders of thyroid dysfunction. East Mediterr Health J 2005;11(3):459-69.

26) Costa A. On goiters and the stupidity which in some countries accompanies them. Endeavours of Vincenzo Malacarne, from Saluzzo. Panminerva Med 1989;31(2):97-106.

27) Lathan SR. Caroline Hampton Halsted: the first to use rubber gloves in the operating room. Proc (Bayl Univ Med Cent) 2010;23(4):389-92.

28) Sakorafas GH. Historical evolution of thyroid surgery: from the ancient times to the dawn of the 21st century. World J Surg 2010; 34(8):1793-804.

29) Kocher T. Ueber Kropfexstirpation und ihre Folgen. Archiv für Klinische Chirurgie 1883;29:254-337.

30) Harwick RD. Our legacy of thyroid surgery. Am J Surg 1988;156(4): 230-4.

31) Halsted WS, Evans HM. I. The parathyroid glandules. Their blood supply and their preservation in operation upon the thyroid gland. Ann Surg 1907;46(4):489-506.

32) MacCallum WG. The function of the parathyroid glands. JAMA 1912;59:319. 
33) Harrison TS. Thyroid surgery in historical perspective. J Med Liban 1970;23(6):537-51.

34) Crile G. George Crile: an autobiography-volume II. Philadelphia: J. B. Lippincott;1947.

35) Choong C, Kaye AH. Emil theodor kocher (1841-1917). J Clin Neurosci 2009;16(12):1552-4.

36) The Nobel Prize. Theodor Kocher - Biographical [cited 2016 February 4]. Available from: URL: http://nobelprize.org/nobel_prizes/medicine/ laureates/1909/kocher-bio.html.

37) Whonamedit. Biography of Emil Theodor Kocher [cited 2016 February 4]. Available from: URL: http://www.whonamedit.com/ doctor.cfm/1006.html.

38) Busman DC. Theodor Billroth 1829-1894. Acta Chir Belg 2006;106 (6):743-52.

39) Dunhill TP. A discussion on partial thyroidectomy under local anaesthesia, with special reference to exophthalmic goitre: an address introductory to a discussion on the subject. Proc R Soc Med 1912;5 (Surg Sect):61-9.

40) Dunhill TP. Some considerations on the operation for exophthalmic goiter. Br J Surg 1919;7(26):195-210.
41) Joll CA. Diseases of the thyroid gland with special reference to thyrotoxicosis. London: William Heinemann;1932. p.78.

42) Kendall EC, Ostererberg AE. The chemical identification of thyroxin. J Biol Chem 1919;40:265-334.

43) Turner P, Granville-Grossman KL. Effect of adrenergic receptor blockade of the tachycardia of thyrotoxicosis and anxiety state. Lancet 1965;2(7426):1316-8.

44) Soderstrom N. Puncture of goiters for aspiration biopsy. Acta Med Scand 1952;144(3):237-44.

45) Koh YW, Park JH, Kim JW, Lee SW, Choi EC. Clipless and sutureless endoscopic thyroidectomy using only the harmonic scalpel. Surg Endosc 2010;24(5):1117-25.

46) Byeon HK, Holsinger FC, Tufano RP, Chung HJ, Kim WS, Koh $\mathrm{YW}$, et al. Robotic total thyroidectomy with modified radical neck dissection via unilateral retroauricular approach. Ann Surg Oncol 2014;21(12):3872-5.

47) Flisberg K, Lindholm T. Electrical stimulation of the human recurrent laryngeal nerve during thyroid operation. Acta Otolaryngol Suppl 1969;263:63-7.

\section{정답 및 해설}

(4)

해 설 본 증례는 중두개와 접근법을 이용하여 안면신경 감압술을 시행하였다. 수술 중 중뇌막동맥으로부터 출혈을 유의하여야 하며 중뇌막동맥의 내측에 대천추체신경이 위치한다. 경질막 박리는 뒤에서부터 앞으로 진행하는 것이 좋은데 이는 중두 개와 뒤쪽에 중요한 구조물이 적고 유착이 흔하지 않기 때문이다. 미로분절 노출 시에 와우의 기저부와 상반고리관의 팽 대부가 손상되지 않도록 주의하여야 한다. 내이도공(porus) 가까이에는 상추체정맥동 외에 다른 중요한 구조물이 없으므 로 비교적 안전하게 내이도를 찾을수 있다.

참고문헌: 대한이비인후과학회편. 이비인후과학-두경부외과학 개정판. 서울: 일조각;2009. p.995.

연세대학교편. 측두골 해부 실습서. 서울: 군자출판사;2008. 